\title{
An Integrated MCDM for a Medical Company Selection in Health Sector
}

\author{
Seyma Emec (Corresponding author) \\ Industrial Engineering Department, Ataturk University, Erzurum, Turkey \\ E-mail: seyma.yayla@atauni.edu.tr \\ Betul Turanoglu \\ Industrial Engineering Department, Ataturk University, Erzurum, Turkey \\ Sinan Oztas \\ Industrial Engineering Department, Ataturk University, Erzurum, Turkey \\ Gokay Akkaya \\ Industrial Engineering Department, Ataturk University, Erzurum, Turkey
}

\begin{abstract}
The correct choice of the devices used in the health sector is great importance for reduction of the workforce, improving quality and saving time. Therefore, selection of medical company that devices will be provided is an important decision problem. In this study, AHP and fuzzy VIKOR methods were utilized for selection of DNA-RNA-protein isolation device which will be used in a laboratory that conducts scientific research in the Atatürk University Faculty of Medicine. As a result of surveys conducted by responsible experts for the medical selection, 7 criteria were determined and pairwise comparison matrix has been established. Then, weights of criteria determined by AHP and 4 different alternatives were listed by fuzzy VIKOR. To the best of the authors' knowledge, there is no study on the selection of suppliers in the field of health in the literature. It is aimed to contribute to the literature in this respect.
\end{abstract}

Keywords: Medical Company Selection, AHP, Fuzzy VIKOR

DOI: $10.7176 / J S T R / 5-4-09$

\section{Introduction}

Medical device sector is an essential part of health industry along with pharmaceutical industry. Due to improving medicine technology, medical device industry -just as pharmaceutical industry- had an ever increasing use, and this had showed up as health expenses increasing in the whole world. The whole world is taking measures in order to decrease health expenses. Thus, in this study it was intended to select the medical company which is the most qualified one and which is the most appropriate in respect of cost for the procurement of medical devices.

Ataturk University, Medical Faculty, Department of Pharmacology was established in 1966 by the Internal Diseases Specialist Dr. Hasan GACAR. At the Department of Medical Pharmacology, they carry out the scientific studies along with 16 doctoral students and 14 postgraduate students. In the studies performed at the department, it was intended to make medication researches for diseases whose treatment is not available, to perform experiments searching the mechanism of action of available medications, to make researches on the basic pharmacology and clinical pharmacology of recent medications, and to announce these studies to world through scientific magazines.

One of the significant operations performed at the laboratories of department of pharmacology is the isolation of DNA-RNA-Protein. This operation is normally being performed manually, and an operation on 12 samples is taking about 2.5-3 hours. Despite that, complete pure result cannot be obtained. There are devices in the market which perform this operation in a much shorter time. The employees of the laboratory are considering to procure these devices for the operation in subject. They had encountered the selection of medical company from which the device will be procured as a decision problem, and we suggested an integrated AHP (Analytical Hierarchy Process) and Fuzzy VIKOR (VIsekriterijumska optimizacija i KOmpromisno Resenje) method for the solution of that problem. 


\subsection{Literature Survey}

Multi-criteria decision making (MCDM) methods deal with problems of compromise selection of the best solutions from the set of available alternatives according to objectives. Usually neither of the alternatives satisfies all the objectives, therefore satisfactory decision is made instead of optimal one. The literature search is shown in three parts: Studies on sustainable supplier selection (Table 1), on green supplier selection (Table 2) and on supplier selection (Table 3) and studies using MCDM methods.

Table 1. Studies on sustainable supplier selection

\begin{tabular}{|c|c|c|c|}
\hline $\begin{array}{l}\text { Author/s and Year of } \\
\text { Publication }\end{array}$ & Application Areas & $\begin{array}{l}\text { Application } \\
\text { Location }\end{array}$ & MCDM Methods \\
\hline Liu et al.,2019 & $\begin{array}{c}\text { A watch manufacturing } \\
\text { company }\end{array}$ & - & $\begin{array}{c}\text { Combining the IVIUL } \\
\text { (interval-valued intuitionistic } \\
\text { uncertain linguistic)-BWM } \\
\text { (Best-Worst Method) with the } \\
\text { IVIUL-AQM (alternative } \\
\text { queuing method) }\end{array}$ \\
\hline Yu et al., 2019 & $\begin{array}{l}\text { a home appliances } \\
\text { manufacturer }\end{array}$ & China & $\begin{array}{c}\text { TOPSIS (Technique For } \\
\text { Order Preference By } \\
\text { Similarity To An Ideal } \\
\text { Solution) and IVPFS } \\
\text { (interval-valued Pythagorean } \\
\text { fuzzy set) }\end{array}$ \\
\hline Xu et al.2019 & $\begin{array}{l}\text { A long-term partner for } \\
\text { company }\end{array}$ & - & $\begin{array}{c}\text { IT2FSs (interval } \\
\text { type-2 fuzzysets) AHP Sort II } \\
\text { Model }\end{array}$ \\
\hline Rashidi and Cullinane 2019 & $\begin{array}{l}\text { set of logistics service } \\
\text { providers }\end{array}$ & Sweden & $\begin{array}{c}\text { Fuzzy DEA (Data } \\
\text { Envelopment Analysis ) and } \\
\text { Fuzzy TOPSIS }\end{array}$ \\
\hline Pishchulov et al.2019 & $\begin{array}{l}\text { medium-sized company in the } \\
\text { wood construction industry }\end{array}$ & Switzerland & Voting AHP \\
\hline Abdel-Baset et al. 2019 & A large importing company & Egypt & $\begin{array}{c}\text { Neutrosophic ANP (Analytic } \\
\text { Network Process) } \\
\text { And VIKOR }\end{array}$ \\
\hline Costa et al. 2018 & a manufacturing industry & India & $\begin{array}{l}\text { ELECTRE (elimination and } \\
\text { et choice translating reality) } \\
\text { TRI- nC method }\end{array}$ \\
\hline KhanMohammadi et al. 2018 & in the petrochemical industry & - & $\begin{array}{l}\text { Graph theory and matrix } \\
\text { approach (GTMA) }\end{array}$ \\
\hline Ghoushchi et al. 2018 & A chemical industry company & Qazvin & $\begin{array}{c}\text { on goal programming }(\mathrm{GP})- \\
\text { DEA }\end{array}$ \\
\hline Azimifard et al. 2018 & A steel industry & Iran & AHP and TOPSIS \\
\hline
\end{tabular}


Table 2. Studies on green supplier selection

\begin{tabular}{|c|c|c|c|}
\hline $\begin{array}{l}\text { Author/s and Year of } \\
\text { Publication }\end{array}$ & Application Areas & Application Location & MCDM Methods \\
\hline Chen et al. 2019 & The panel manufacture & - & $\begin{array}{l}\text { Fuzzy six sigma quality } \\
\text { indices }\end{array}$ \\
\hline Haghighi et al. 2019 & The food sector. & Iranian & IT2FSs \\
\hline Yucesan et al. 2019 & $\begin{array}{l}\text { An injection molding } \\
\text { facility }\end{array}$ & Turkey & IT2F TOPSIS \\
\hline Liu et al. 2019 & $\begin{array}{l}\text { A manufacturing } \\
\text { enterprises }\end{array}$ & - & $\begin{array}{l}\text { The hesitant fuzzy } \\
\text { prioritized weighted } \\
\text { average (HFPWA) }\end{array}$ \\
\hline Darminto et al. 2018 & $\begin{array}{l}\text { One of the industries in } \\
\text { the diesel engine } \\
\text { exporting company }\end{array}$ & Indonesia & $\begin{array}{l}\text { Fuzzy Analytical Network } \\
\text { Process (FANP) }\end{array}$ \\
\hline Jiang et al. 2018 & An automotive industry & Taiwan & $\begin{array}{c}\text { GREY DEMATEL } \\
\text { (Decision making trial and } \\
\text { evaluation laboratory)- } \\
\text { BASED ANP (GDANP) }\end{array}$ \\
\hline Quan et al. 2018 & A real estate company & China. & $\begin{array}{c}\text { a modified } \\
\text { MULTIMOORA (Multi- } \\
\text { Objective Optimization by } \\
\text { Ratio Analysis plus the } \\
\text { Full Multiplicative From) }\end{array}$ \\
\hline
\end{tabular}


Table 3. Studies on supplier selection

\begin{tabular}{|c|c|c|c|}
\hline $\begin{array}{l}\text { Author/s and Year of } \\
\text { Publication }\end{array}$ & Application Areas & $\begin{array}{l}\text { Application } \\
\text { Location }\end{array}$ & MCDM Methods \\
\hline Hajek and Froelich & A supplier selection task & - & IVIFCM-TOPSIS \\
\hline Huang et al. 2019 & $\begin{array}{l}\text { A manufacturing } \\
\text { company }\end{array}$ & - & $\begin{array}{l}\text { MS-DIFDT (A multi-scale } \\
\text { IF decision table) }\end{array}$ \\
\hline $\begin{array}{l}\text { Çalı and Balaman et al. } \\
2019\end{array}$ & In automotive sector & - & $\begin{array}{c}\text { IFS ELECTRE AND } \\
\text { VIKOR }\end{array}$ \\
\hline Fu 2019 & $\begin{array}{l}\text { The best catering selection for } \\
\text { ABC airline }\end{array}$ & - & $\begin{array}{c}\text { AHP-ARAS (Additive } \\
\text { Ratio Assessment)- MCGH } \\
\text { Multi-choice goal } \\
\text { programming }\end{array}$ \\
\hline Wang and Chen 2019 & $\begin{array}{l}\text { The existing literature } \\
\text { problem }\end{array}$ & - & $\begin{array}{c}\text { A partial-consensus } \\
\text { posterior-aggregation FAHP } \\
\text { (PCPA-FAHP) approach }\end{array}$ \\
\hline Suraraksa and Shin 2019 & İn automotive industry & Thailand & AHP \\
\hline Alkahtani et al. 2019 & $\begin{array}{l}\text { X company produces } \\
\text { chemicals }\end{array}$ & - & $\begin{array}{c}\text { Fuzzy TOPSIS and Fuzzy } \\
\text { AHP }\end{array}$ \\
\hline Stević et al. 2019 & $\begin{array}{l}\text { A company for the } \\
\text { production of plastic bags }\end{array}$ & - & $\begin{array}{c}\text { Fuzzy AHPa nd Fuzzy } \\
\text { EDAS ((Evaluation based } \\
\text { on Distance from Average } \\
\text { Solution) }\end{array}$ \\
\hline Phumchusri et al. 2019 & A raw material suppliers & Thailand & AHP \\
\hline Kumar et. al. 2018 & A leavy locomotive firm & Indian & TOPSIS and AHP \\
\hline Wang et al. 2018 & $\begin{array}{l}\text { In the food processing } \\
\text { industry }\end{array}$ & Vietnam. & $\begin{array}{c}\text { A hybrid FAHP and GDEA } \\
\text { model } \\
\text { green data envelopment } \\
\text { analysis }\end{array}$ \\
\hline Wang et al. 2018 & In the Gas and Oil Industry & Vietnam. & $\begin{array}{c}\text { Hybrid SCOR Metrics, } \\
\text { AHP, and TOPSIS }\end{array}$ \\
\hline Chen et al. 2018 & A food industry & China & $\begin{array}{c}\text { A hybrid model that } \\
\text { combines total interpretive } \\
\text { structural modeling (TISM) } \\
\text { and FANP }\end{array}$ \\
\hline Liao et al. 2018 & An aircraft manufacturer & - & $\begin{array}{c}\text { A new hesitant fuzzy } \\
\text { linguistic ORESTE } \\
\text { (Organization, Rangement } \\
\text { Et Synthese De Donnes } \\
\text { Relationnelles) }\end{array}$ \\
\hline Diouf and Kwak 2018 & A printing industry & Korea & $\begin{array}{c}\text { Fuzzy AHP, DEA, and } \\
\text { Managerial Analysis }\end{array}$ \\
\hline Abdel-Basset et al. 2018 & A distribution company & Turkey & Neutrosophic DEMATEL \\
\hline Wang and Tsai 2018 & $\begin{array}{l}\text { A solar Panel Supplier } \\
\text { Selection }\end{array}$ & Taiwanese & FAHP and DEA \\
\hline $\begin{array}{c}\text { Büyüközkan, AND Göçek } \\
2018\end{array}$ & $\begin{array}{l}\text { Digital } \\
\text { Supply } \\
\text { Chain }\end{array}$ & Turkey & IVIF AHP and IVIF ARAS \\
\hline Joshi and Kumar 2018 & An automobile manufacturer & - & $\begin{array}{l}\text { An extended VIKOR } \\
\text { method }\end{array}$ \\
\hline Grandhi and Wibowo 2018 & $\begin{array}{l}\text { most suitable solar energy } \\
\text { supplier }\end{array}$ & India & Fuzzy MCDM \\
\hline Abdel-Basset et al. 2018 & food industry & Egypt & $\begin{array}{l}\text { A Hybrid Neutrosophic } \\
\text { Group ANP-TOPSIS }\end{array}$ \\
\hline
\end{tabular}


To the best of the authors' knowledge, there is no study on the selection of suppliers in the field of health in the literature. It is aimed to contribute to the literature in this respect.

\section{Methodology}

\subsection{Analytical Hierarchy Process (AHP)}

AHP was first developed by Saaty in 1971 and is available in many studies in the literature. Saaty proposed the scale of significance given by Table 4, which includes decision numbers from 1 to 9 (Subramanian ve Ramanathan, 2012). When determining factor weights with AHP method, the steps to be followed are as follows: (Emeç and Akkaya, 2018; Akkaya et al. 2015 ):

Table 4. Linguistic and Corresponding Numeric AHP

\begin{tabular}{|c|l|}
\hline AHP lingustic scale & AHP numeric scale \\
\hline 1 & Equally important \\
\hline 3 & Moderately more important \\
\hline 5 & Strongly more important \\
\hline 7 & Demonstrated more important \\
\hline 9 & Compromely more important \\
\hline $2,4,6,8$ & \\
\hline
\end{tabular}

Step1: Using the scale values given in Table 1, a pairwise comparison of the factors is made and pairwise comparison matrices as in Equation 1 are generated.

$D=\left[\begin{array}{ccc}1 & \cdots & a_{1 n} \\ \vdots & \ddots & \vdots \\ a_{m 1} & \cdots & 1\end{array}\right]$

where $a_{i j}=\frac{1}{a_{j i}}, a_{i j}>0$

Step 2: The generated comparison matrix is normalized. For this, column totals are taken, and each value is divided by its column sum. In this way, normalized decision matrix is obtained.

$a_{i 1}=\frac{a_{i 1}}{\sum_{i=1}^{m} a_{i 1}} i=1 ; 2, \ldots, m$

Step 3: Line averages are taken to calculate factor weights.

$w_{i}=\frac{\sum_{j=1}^{n} a_{i j,}}{n} i=1,2 \ldots, m j=1,2, \ldots, n$

\subsection{Fuzzy VIKOR Technique}

Fuzzy VIKOR technique is applying fuzzy logic to VIKOR technique. Method offers rational and systematic process for the best and compromise solution by handling linguistic expressions. In this process, implemented steps are as follows (Emeç and Akkaya, 2018): 
Stage 1: Firstly, $\mathrm{n}$ decison makers, $\mathrm{m}$ alternatives and $\mathrm{k}$ criteria are determined to solve the problems.

Stage 2: Alternatives and criteria are evaluated by experts using the linguistic variables given in Table 5. Linguistic variables are used to determine the weight of criteria and evaluate the alternatives. However, stochastic AHP are used when determining criteria weight in the study.

Table 5. Linguistic Variables Used in Fuzzy VIKOR

\begin{tabular}{|l|c|}
\hline Linguistic Variables & Triangular Fuzzy Numbers \\
\hline Very poor & $(0,0,1)$ \\
\hline Poor & $(0,1,3)$ \\
\hline Moderately poor & $(1,3,5)$ \\
\hline Moderate & $(3,5,7)$ \\
\hline Moderately good & $(5,7,9)$ \\
\hline Good & $(7,9,10)$ \\
\hline Very good & $(9,10,10)$ \\
\hline
\end{tabular}

Stage 3: Evaluation of decision makers are combined and integrated fuzzy weight of each criterion is calculated with the aid of Eq. (4).

$\widetilde{\mathrm{w}_{\mathrm{j}}}=\frac{1}{\mathrm{n}}\left[\sum_{\mathrm{e}=1}^{\mathrm{n}} \widetilde{\mathrm{w}}_{\mathrm{j}}^{\mathrm{e}}\right] \quad \mathrm{j}=1,2, \ldots, \mathrm{k}$

Importance weight of ith alternative according to jth criteria is calculated with the aid of Eq. (5).

$\widetilde{\mathrm{x}_{\mathrm{lj}}}=\frac{1}{\mathrm{n}}\left[\sum_{\mathrm{e}=1}^{\mathrm{n}} \widetilde{\mathrm{x}_{1 \mathrm{j}}}\right] \mathrm{e}=1,2, \ldots, \mathrm{m}$

Stage 4: Fuzzy decision matrix is created.

$\widetilde{\mathrm{D}}=\left[\begin{array}{ccc}\widetilde{\mathrm{x}_{11}} & \cdots & \widetilde{\mathrm{x}_{1 \mathrm{k}}} \\ \vdots & \ddots & \vdots \\ \widetilde{\mathrm{x}_{\mathrm{m} 1}} & \cdots & \widetilde{\mathrm{x}_{\mathrm{mk}}}\end{array}\right] \mathrm{i}=1,2, \ldots, \mathrm{m} \mathrm{j}=1,2, \ldots, \mathrm{k}$

$\widetilde{W}=\left[\widetilde{w_{1}} ; \widetilde{w_{2}} ; \ldots ; \widetilde{w_{k}}\right], j=1,2, \ldots, \mathrm{k}$

Where $\widetilde{\mathrm{x}_{\mathrm{lj}}}$ is the degree of $\mathrm{Ai}$ alternative according to $\mathrm{Cj}$ criteria, $\widetilde{\mathrm{w}_{1 \mathrm{j}}}$ is importance weight of jth criteria

Stage 5: Fuzzy best $\left({\widetilde{\mathrm{f}_{\mathrm{j}}^{*}}}^{*}\right)$ and worst $\left(\widetilde{\mathrm{f}_{\mathrm{j}}^{-}}\right)$values are determined.

$\left(\widetilde{\mathrm{f}_{\mathrm{j}}^{*}}\right)=\max _{\mathrm{i}} \widetilde{\mathrm{x}_{\mathrm{lj}}},\left(\widetilde{\mathrm{f}_{\mathrm{j}}^{-}}\right)=\min _{\mathrm{i}} \widetilde{\mathrm{x}_{\mathrm{lj}}}$

Stage 6: $\widetilde{\mathrm{S}_{1}}$ and $\widetilde{\mathrm{R}_{1}}$ values are calculated.

$\widetilde{\mathrm{S}_{1}}=\sum_{\mathrm{j}=1}^{\mathrm{k}} \widetilde{\mathrm{w}_{\mathrm{j}}}\left(\widetilde{\mathrm{f}_{\mathrm{j}}^{*}}-\widetilde{\mathrm{x}_{\mathrm{j}}}\right) /\left(\widetilde{\mathrm{f}_{\mathrm{j}}^{*}}-\widetilde{\mathrm{f}_{\mathrm{j}}^{-}}\right)$ 
$\widetilde{\mathrm{R}_{1}}=\max _{\mathrm{j}}\left[\sum_{\mathrm{j}=1}^{\mathrm{k}} \widetilde{\mathrm{W}_{\mathrm{j}}}\left(\widetilde{\mathrm{f}_{\mathrm{j}}^{*}}-\widetilde{\mathrm{x}_{\mathrm{lj}}}\right) /\left(\widetilde{\mathrm{f}_{\mathrm{j}}^{*}}-\widetilde{\mathrm{f}_{\mathrm{j}}^{-}}\right)\right]$

$\widetilde{\mathrm{S}_{1}}$ is total of criteria value distance to fuzzy best value. $\widetilde{\mathrm{R}_{1}}$ is the maximum distance of alternatives Ai to the fuzzy worst value according to jth criteria. In other words, $\widetilde{\mathrm{S}_{1}}$ and $\widetilde{\mathrm{R}}_{1}$ values represent moderate and the worst scores of Ai alternatives.

Stage 7: $\widetilde{\mathrm{S}^{*}}, \widetilde{\mathrm{S}^{-}}, \widetilde{\mathrm{R}^{*}}, \widetilde{\mathrm{R}^{-}}$and $\widetilde{\mathrm{Q}_{1}}$ values are calculated.

$\widetilde{S^{*}}=\min _{i} \widetilde{S_{1}}, \widetilde{S^{-}}=\max _{i} \widetilde{S_{1}}$

$\widetilde{\mathrm{R}^{*}}=\min _{\mathrm{i}} \widetilde{\mathrm{R}_{1}}, \widetilde{\mathrm{R}^{-}}=\max _{\mathrm{i}} \widetilde{\mathrm{R}_{1}}$

$\overline{Q_{1}}=\frac{v\left(\widetilde{S_{1}}-\overline{S^{*}}\right)}{\left(\widetilde{S^{-}}-\bar{S}^{*}\right)}+\frac{(1-v)\left(\widetilde{R_{1}}-\bar{R}^{*}\right)}{\left(\widetilde{R^{-}-\bar{R}^{*}}\right)}$

where $\widetilde{\mathrm{S}^{*}}$ represents maximum benefit of the group and $\widetilde{\mathrm{R}^{*}}$ represents minimum regret of opposite view. $\overline{Q_{1}}$ index is calculated together with the assesment group of benefits and minimum regret. $v$ value represents weight of strategy which ensures maximum group benefit. Compromise can be provided with "majority vote" $(v>0.5)$, "compromise" $(v=0.5)$ or "rejection" $(v<0.5)$.

Stage 8: $Q_{i}$ index is obtained by defuzzification using Eq. 14. There are different defuzzification methods in literature. BNP (Best Non Fuzzy Performance Value) proposed by Hsiesh et all., 2004 is used for defuzzification in this study. In the equation; $u_{i}$ is the upper value of triangular fuzzy number, $m_{i}$ is the median value of triangular fuzzy number and $l_{i}$ is the lower value of triangular fuzzy number.

$\mathrm{BNP}=\left[\left(u_{i}-l_{i}\right)+\left(m_{i}-l_{i}\right)\right] / 3+l_{i} \quad V_{i}$

$\mathrm{Q}_{i}$ indexes are arranged in increasing order. Alternative which have lowest $\mathrm{Q}_{i}$ value is the best alternative.

Stage 9: In this stage, compromise solution is determined. If following two conditions are satisfied, obtained solution by using $Q_{i}$ index is compromise solution $\left(a^{l}\right)$

Condition 1: acceptable advantage: with condition 1, it is established that there is a clear difference between the best and closest options.

$\mathrm{Q}\left(a^{l l}\right)-\mathrm{Q}\left(a^{l}\right) \geq \mathrm{DQ}$

In the equation a value is an alternative in the second when ordered $Q_{i}$ values.

$\mathrm{DQ}=1 /(\mathrm{m}-1) \quad($ eğer $\mathrm{m} \leq 4$ ise $\mathrm{DQ}=0.25)$

Condition 2: acceptable stability: a alternative must also be the best alternative when ordered based on $\mathrm{S}$ and/or $\mathrm{R}$ values. If $\mathrm{Q}\left(a^{(m)}\right)-\mathrm{Q}\left(a^{l}\right)<\mathrm{DQ}$, condition 1 is not satisfied, $\left.a^{(m)}\right)$ and $a^{l}$ are the same compromise solutions. Because of similar compromise solution $\left(a^{l}, a^{l}, \ldots, a^{(m)}\right), a^{l}$ does not have comparative advantage. If condition 2 is not satisfied, decision making is not stable although a has a comparative advantage. Therefore compromise solution of $a^{l}$ and $a^{l}$ is similar.

Stage 10: Finally, the best alternative is selected. Alternative which has minimum $Q$ value is the best solution. 


\section{Application}

This study benefited from the AHP and Fuzzy VIKOR methods for the selection of DNA-RNA-Protein isolation device to be used at laboratories where scientific researches of Ataturk University Medical Faculty are being carried out. As the result of questionnaires applied on specialists being responsible for the selection of medicals, 7 criteria (brand, cost, quality, time, technical service, customer representative, diversity) were determined and brief description of criteria of the implementation is shown Figure 1 and 4 alternative (A, B, C, D) medical companies were selected for evaluation by the fuzzy VIKOR method.

Quality
- It is the faultless result generation rate of test results of the device procured from the
medical company.
when compared with the prices of other companies in the market.
- The time criterion is addressed in respect of delivery period of the product to customer as
from its request from the company.
Time
Brand
known in the market..
- It is the technical service of the medical company in case of any malfunction or problem
regarding the procured device.
representative
- It is satisfying the customer with the response when the customer requires to obtain
information regarding the device.

Figure 1. The Description of Criteria of the Implementation

The decision hierarchy of the selection of medical company is shown in Figure 2. Then these criteria and alternatives were evaluated by the purchasing officer and the PCM was formed. By using the data in the formed matrix, the importance degrees of criteria were calculated by the AHP method. And then, the assessment of the alternatives was performed by an individual who is specialized in the field and who is responsible for the selection of medical company, and linguistic variables were used in the assessment.

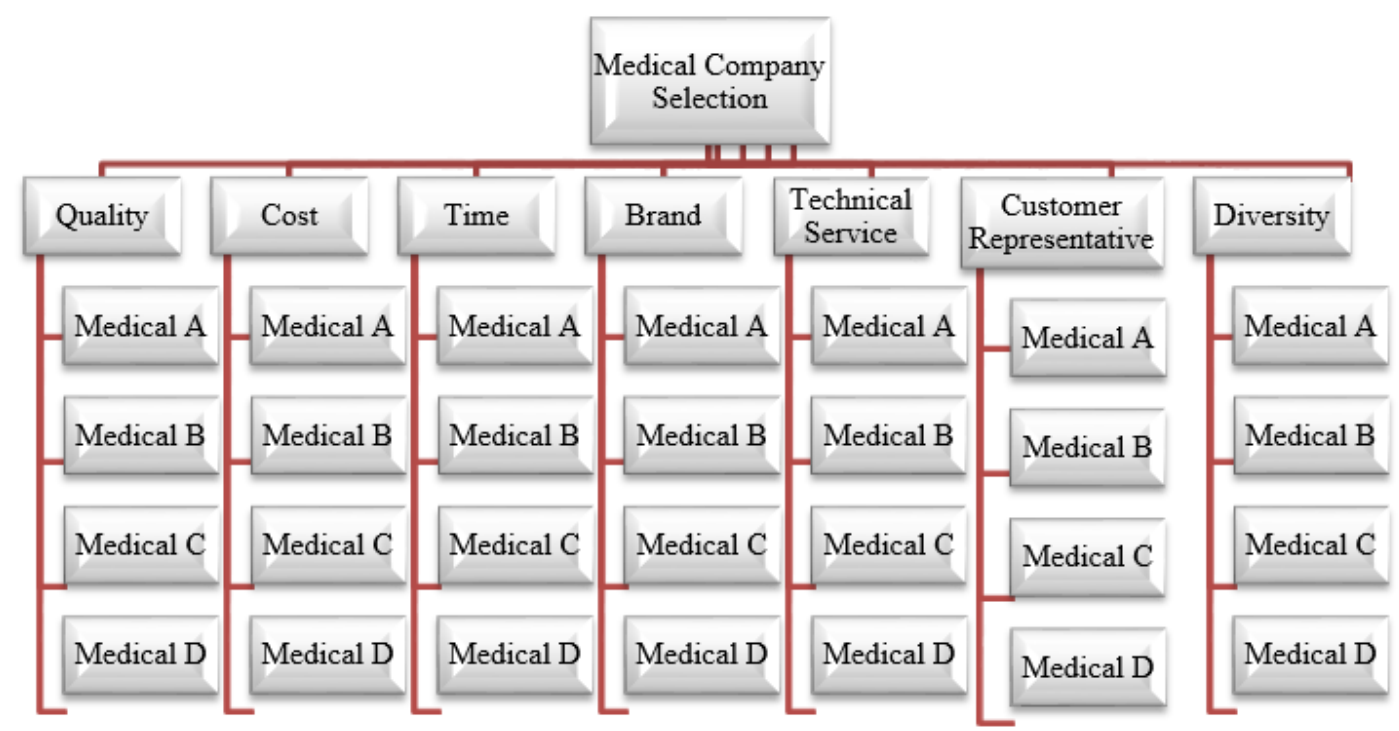

Figure 2. Decision Hierarchy for Medical Company Selection

The pairwise comparison matrix was created by using Table 4. The criteria weights were found by AHP method as 0.09 (brand), 0.08 (cost), 0.17 (quality), 0.09 (time), 0.29 (technical service), 0.16 (customer representative) and 0.10 (diversity). Subsequently, alternatives were evaluated by using Table 5 and fuzzy decision matrix was formed as in Table 6. 
Table 6. The Fuzzy Decision Matrix

\begin{tabular}{|l|l|l|l|l|l|l|l|}
\hline Ariteria & Brand & Cost & Quality & Time & $\begin{array}{c}\text { Technical } \\
\text { Service }\end{array}$ & $\begin{array}{c}\text { Customer } \\
\text { Representative }\end{array}$ & Diversity \\
\hline Medical A & $(5,7,9)$ & $(7,9,10)$ & $(9,10,10)$ & $(7,9,10)$ & $(5,7,9)$ & $(5,7,9)$ & $(5,7,9)$ \\
\hline Medical B & $(7,9,10)$ & $(5,7,9)$ & $(7,9,10)$ & $(5,7,9)$ & $(5,7,9)$ & $(5,7,9)$ & $(5,7,9)$ \\
\hline Medical C & $(3,5,7)$ & $(7,9,10)$ & $(5,7,9)$ & $(5,7,9)$ & $(5,7,9)$ & $(5,7,9)$ & $(3,5,7)$ \\
\hline Medical D & $(5,7,9)$ & $(5,7,9)$ & $(5,7,9)$ & $(5,7,9)$ & $(3,5,7)$ & $(3,5,7)$ & $(3,5,7)$ \\
\hline
\end{tabular}

The best and worst fuzzy values were determined using equality 8 . Fuzzy best and fuzzy worst values for the criteria are shown in Table 7. Then, the fuzzy $\widetilde{S}_{1}$ and $\widetilde{\mathrm{R}}_{1}$ values were determined using equalities 9 and 10 in Table 8.

Table 7. The Fuzzy Best Value and The Fuzzy Worst Values

\begin{tabular}{|l|c|c|}
\hline Criteria & $\left(\widetilde{\mathrm{f}_{\mathrm{j}}^{*}}\right)$ & $\left(\widetilde{\mathrm{f}_{\mathrm{f}}^{-}}\right)$ \\
\hline Brand & $(7,9,10)$ & $(3,5,7)$ \\
\hline Cost & $(7,9,10)$ & $(5,7,9)$ \\
\hline Quality & $(9,10,10)$ & $(5,7,9)$ \\
\hline Time & $(7,9,10)$ & $(5,7,9)$ \\
\hline Technical Service & $(5,7,9)$ & $(3,5,7)$ \\
\hline Customer Representative & $(5,7,9)$ & $(3,5,7)$ \\
\hline Diversity & $(5,7,9)$ & $(3,5,7)$ \\
\hline
\end{tabular}

Table 8. $\widetilde{\mathrm{S}_{1}}$ and $\widetilde{\mathrm{R}_{1}}$ Values

\begin{tabular}{|c|c|c|}
\hline Alternatives & $\widetilde{S}_{1}$ & $\widetilde{\mathrm{R}_{1}}$ \\
\hline Medical A & $(0.045,0.045,0.030)$ & $(0.045,0.045,0.030)$ \\
\hline Medical B & $(0.255,0.227,0.170)$ & $(0.090,0.090,0.090)$ \\
\hline Medical C & $(0.450,0.450,0.450)$ & $(0.170,0.170,0.170)$ \\
\hline Medical D & $(0.935,0.935,0.935)$ & $(0.290,0.290,0.290)$ \\
\hline
\end{tabular}

Fuzzy maximum and minimum $\widetilde{\mathrm{S}_{1}}$ and $\widetilde{\mathrm{R}_{1}}$ values $\left(\widetilde{\mathrm{S}^{*}}, \widetilde{\mathrm{S}^{-}}, \widetilde{\mathrm{R}^{*}}, \widetilde{\mathrm{R}^{-}}\right.$values$)$were calculated with the help of the equalities 11 and 12 and these values are shown in Table 9.

Table 9. $\widetilde{\mathrm{S}^{*}}, \widetilde{\mathrm{S}^{-}}, \widetilde{\mathrm{R}^{*}}, \widetilde{\mathrm{R}^{-}}$values

\begin{tabular}{|l|l|l|l|}
\hline & $\mathrm{I}$ & $\mathrm{m}$ & $\mathrm{u}$ \\
\hline$\widetilde{S^{*}}$ & 0.045 & 0.045 & 0.030 \\
\hline$\widetilde{S^{-}}$ & 0.935 & 0.935 & 0.935 \\
\hline$\widetilde{R^{*}}$ & 0.045 & 0.045 & 0.030 \\
\hline$\widetilde{R^{-}}$ & 0.290 & 0.290 & 0.290 \\
\hline
\end{tabular}

Finally, the fuzzy $\widetilde{Q_{1}}$ index were found using equality 13 and fuzzy values are converted to crisp values 
using equation 14. Alternatives are ranked according to the crisp values of $S_{i}, R_{i}$ and $\mathrm{Q}_{i}$. Alternative Ranking is shown in Table 10. The results of the calculation showed that Medical A which is in the first rank in the alternative ranking was the best alternative.

Table 10. Alternative Ranking

\begin{tabular}{|c|c|c|c|c|c|c|c|}
\hline & \multirow{2}{*}{$\overline{Q_{1}}$} & \multicolumn{2}{|c|}{$Q_{i}$} & \multicolumn{2}{|c|}{$S_{i}$} & \multicolumn{2}{|c|}{$R_{i}$} \\
\hline & & index & ranking & index & ranking & index & ranking \\
\hline Medical A & $(0,0,0)$ & 0 & 1 & 0,04 & 1 & 0,04 & 1 \\
\hline Medical B & $(0.210,0,222,0.308)$ & 0,247 & 2 & 0,22 & 2 & 0,09 & 2 \\
\hline Medical C & $(0.483,0.483,0.501)$ & 0,489 & 3 & 0,45 & 3 & 0,17 & 3 \\
\hline Medical D & $(1,1,1)$ & 1 & 4 & 0,94 & 4 & 0,29 & 4 \\
\hline
\end{tabular}

Condition 1: Acceptable advantage: According to equalities 15 and 16, because of $\mathrm{Q}\left(a^{(l)}\right)-\mathrm{QQ}\left(a^{l}\right)=0,247-$ $0=0,25 \geq 0,25, \mathrm{Q}\left(a^{(l u)}\right)-\mathrm{Q}\left(a^{l}\right)=0,489-0 \geq 0,25$ and $\mathrm{Q}\left(a^{(l u)}\right)-\mathrm{Q}\left(a^{l}\right)=1-0 \geq 0,25$, condition 1 is satisfied.

Condition 2: Acceptable stability: An alternative must also be the best alternative when ordered based on $\mathrm{S}$ and/or $\mathrm{R}$ values. If $\mathrm{Q}\left(a^{(m)}\right)-\mathrm{Q}\left(a^{l}\right)<\mathrm{D} \mathrm{Q}$, if condition 1 is not satisfied, $a^{(m)}$ and $a^{l}$ are the same compromise solutions. Because of similar compromise solution $\left(a^{l}, a^{l}, \ldots,{ }^{m}\right), a^{l}$ does not have a comparative advantage. If condition 2 is not satisfied, decision making is not stable although has a comparative advantage. Therefore compromise solution of $a^{l}$ and $a^{l}$ is similar. Looking at table 10, Medical A has been the best alternative all ranked according to index. Hence condition 2 is satisfied.

\section{Conclusion}

In this study, it was benefited from the AHP and Fuzzy VIKOR methods for the selection of DNA-RNAProtein isolation device to be used at laboratories where scientific researches of Ataturk University Medical Faculty are being carried out. For the problem of selection being addressed in this study, AHP and fuzzy VIKOR approaches among multi criteria decision making techniques- were used together and an assessment was made. The criteria affecting the selection of medical company were determined as quality, cost, time, brand, technical service, customer representative and diversity in the direction of the opinions of decision makers. These criteria were weighted by AHP, and the assessment of alternatives was performed by using the fuzzy VIKOR approach. When the results were examined, it was observed that Medical A was the best alternative. Medical B, Medical C and Medical D are followed, respectively. In the following studies, different multi criteria decision making methods can be used individually or together, and the results can be compared and, the proposed method can be applied to different problems. For different regions, the medical company specific problem can be addressed by increasing the number of alternatives and criteria.

\section{References}

1. Liu, H. C., Quan, M. Y., Li, Z., \& Wang, Z. L. A new integrated MCDM model for sustainable supplier selection under interval-valued intuitionistic uncertain linguistic environment. Information Sciences. 2019.

2. Yu, C., Shao, Y., Wang, K., \& Zhang, L. A group decision making sustainable supplier selection approach using extended TOPSIS under interval-valued Pythagorean fuzzy environment. Expert Systems with Applications, 121, 1-17, 2019.

3. Xu, Z., Qin, J., Liu, J., \& Martínez, L. Sustainable supplier selection based on AHPSort II in interval type-2 fuzzy environment. Information Sciences, 483, 273-293, 2019.

4. Rashidi, K., \& Cullinane, K. A comparison of fuzzy DEA and fuzzy TOPSIS in sustainable supplier selection: Implications for sourcing strategy. Expert Systems with Applications, 121, 266-281, 2019. 
5. Pishchulov, G., Trautrims, A., Chesney, T., Gold, S., \& Schwab, L. The Voting Analytic Hierarchy Process Revisited: A Revised Method with Application to Sustainable Supplier Selection. International Journal of Production Economics, 2019.

6. Abdel-Baset, M., Chang, V., Gamal, A., \& Smarandache, F. An integrated neutrosophic ANP and VIKOR method for achieving sustainable supplier selection: A case study in importing field. Computers in Industry, 106, 94-110, 2019.

7. Costa, A. S., Govindan, K., \& Figueira, J. R., Supplier classification in emerging economies using the ELECTRE TRI-nC method: A case study considering sustainability aspects. Journal of Cleaner Production, 201, 925-947, 2018.

8. KhanMohammadi, E., Talaie, H., Safari, H., \& Salehzadeh, R., Supplier evaluation and selection for sustainable supply chain management under uncertainty conditions. International Journal of Sustainable Engineering, 1-15, 2018.

9. Ghoushchi, S. J., Milan, M. D., \& Rezaee, M. J. Evaluation and selection of sustainable suppliers in supply chain using new GP-DEA model with imprecise data. Journal of Industrial Engineering International, 1-13, 2018.

10. Azimifard, A., Moosavirad, S. H., \& Ariafar, S. Selecting sustainable supplier countries for Iran's steel industry at three levels by using AHP and TOPSIS methods. Resources Policy, 57, 30-44, 2018.

11. Chen, K. S., Wang, C. H., \& Tan, K. H. Developing a Fuzzy Green Supplier Selection Model Using Six Sigma Quality Indices. International Journal of Production Economics, 2019.

12. Haghighi, M. H., Mousavi, S. M., \& Mohagheghi, V. A new soft computing model based on linear assignment and linear programming technique for multidimensional analysis of preference with interval type-2 fuzzy sets. Applied Soft Computing, 2019.

13. Yucesan, M., Mete, S., Serin, F., Celik, E., \& Gul, M. An Integrated Best-Worst and Interval Type-2 Fuzzy TOPSIS Methodology for Green Supplier Selection. Mathematics, 7(2), 182, 2019.

14. Liu, Y., Jin, L., \& Zhu, F. A Multi-Criteria Group Decision Making Model for Green Supplier Selection under the Ordered Weighted Hesitant Fuzzy Environment. Symmetry, 11(1), 17, 2019.

15. Darminto, P., Erpita, R., \& Trio, B. P. U. Implementation of Green Procurement in Supplier Selection of PT Kubota Indonesia with Fuzzy Analytical Network Process Approach (FANP). In E3S Web of Conferences (Vol. 73, p. 09021). EDP Sciences , 2018.

16. Jiang, P., Hu, Y. C., Yen, G. F., \& Tsao, S. J. Green supplier selection for sustainable development of the automotive industry using grey decision-making. Sustainable Development, 26(6), 890903,2018

17. Quan, M. Y., Wang, Z. L., Liu, H. C., \& Shi, H. A hybrid MCDM approach for large group green supplier selection with uncertain linguistic information. IEEE Access, 6, 50372-50383, 2018.

18. Hajek, P., \& Froelich, W. Integrating TOPSIS with Interval-Valued Intuitionistic Fuzzy Cognitive Maps for Effective Group Decision Making. Information Sciences, 2019.

19. Huang, B., Li, H., Feng, G., \& Zhou, X. Dominance-based rough sets in multi-scale intuitionistic fuzzy decision tables. Applied Mathematics and Computation, 348, 487-512, 2019.

20. Çalı, S., \& Balaman, Ş. Y. A novel outranking based multi criteria group decision making methodology integrating ELECTRE and VIKOR under intuitionistic fuzzy environment. Expert Systems with Applications, 119, 36-50, 2019. 
21. Fu, Y. K. An integrated approach to catering supplier selection using AHP-ARAS-MCGP methodology. Journal of Air Transport Management, 75, 164-169, 2019.

22. Wang, Y. C., \& Chen, T. C. T. A Partial-Consensus Posterior-Aggregation FAHP MethodSupplier Selection Problem as an Example. Mathematics, 7(2), 179, 2019.

23. Suraraksa, J., \& Shin, K. S. Comparative Analysis of Factors for Supplier Selection and Monitoring: The Case of the Automotive Industry in Thailand. Sustainability, 11(4), 981, 2019.

24. Alkahtani, M., Al-Ahmari, A., Kaid, H., \& Sonboa, M. Comparison and evaluation of multicriteria supplier selection approaches: A case study. Advances in Mechanical Engineering, 11(2), $1687814018822926,2019$.

25. Stević, Ž., Vasiljević, M., Puška, A., Tanackov, I., Junevičius, R., \& Vesković, S. Evaluation of suppliers under uncertainty: a multiphase approach based on fuzzy AHP and fuzzy EDAS. Transport, 34(1), 52-66 2019.

26. Phumchusri, N., Tangsiriwattana, S., \& Luangiarmekorn, P. Supplier Selection Method: A Casestudy on a Car Seat Manufacturer in Thailand. In 2018 IEEE International Conference on Industrial Engineering and Engineering Management (IEEM) (pp. 46-50). IEEE, 2018.

27. Kumar, R., Padhi, S. S., \& Sarkar, A. Supplier Selection of an Indian Heavy Locomotive Manufacturer: An Integrated Approach using Taguchi Loss Function, TOPSIS, and AHP. IIMB Management Review, 2018.

28. Wang, C. N., Nguyen, V. T., Thai, H. T. N., Tran, N. N., \& Tran, T. L. A. Sustainable Supplier Selection Process in Edible Oil Production by a Hybrid Fuzzy Analytical Hierarchy Process and Green Data Envelopment Analysis for the SMEs Food Processing Industry. Mathematics, 6(12), 302, 2018.

29. Wang, C. N., Huang, Y. F., Cheng, I., \& Nguyen, V. A Multi-Criteria Decision-Making (MCDM) Approach Using Hybrid SCOR Metrics, AHP, and TOPSIS for Supplier Evaluation and Selection in the Gas and Oil Industry. Processes, 6(12), 252, 2018.

30. Chen, Y., Wang, S., Yao, J., Li, Y., \& Yang, S. Socially responsible supplier selection and sustainable supply chain development: A combined approach of total interpretive structural modeling and fuzzy analytic network process. Business Strategy and the Environment, 27(8), 1708-1719, 2018.

31.Liao, H., Wu, X., Liang, X., Xu, J., \& Herrera, F. (2018). A New Hesitant Fuzzy Linguistic ORESTE Method for Hybrid Multicriteria Decision Making. IEEE Transactions on Fuzzy Systems, 26(6), 3793-3807, 2018.

32. Diouf, M., \& Kwak, C. Fuzzy AHP, DEA, and Managerial Analysis for Supplier Selection and Development; From the Perspective of Open Innovation. Sustainability, 10(10), 3779 , 2018.

33. ABDEL-BASSET, Mohamed, et al. A hybrid approach of neutrosophic sets and DEMATEL method for developing supplier selection criteria. Design Automation for Embedded Systems, 2018, 1-22.

34. Wang, T. C., \& Tsai, S. Y. Solar panel supplier selection for the photovoltaic system design by using fuzzy multi-criteria decision making (MCDM) approaches. Energies, 11(8), 1989, 2018.

35. Büyüközkan, G., \& Göçer, F. An extension of ARAS methodology under interval valued intuitionistic fuzzy environment for digital supply chain. Applied Soft Computing, 69, 634-654, 2018. 
36. Joshi, R., \& Kumar, S. An intuitionistic fuzzy information measure of order-\$ (।alpha, lbeta) \$\$ with a new approach in supplier selection problems using an extended VIKOR method. Journal of Applied Mathematics and Computing, 1-24, 2018.

37. Grandhi, S., \& Wibowo, S. Application of fuzzy MCDM approach for evaluating and selecting solar energy suppliers. In 2017 13th International Conference on Natural Computation, Fuzzy Systems and Knowledge Discovery (ICNC-FSKD) (pp. 1396-1401). IEEE, 2018.

38. Abdel-Basset, M., Mohamed, M., \& Smarandache, F. A hybrid neutrosophic group ANP-TOPSIS framework for supplier selection problems. Symmetry, 10(6), 226, 2018.

39. Subramanian, N., \& Ramanathan, R. (2012). A review of applications of Analytic Hierarchy Process in operations management. International Journal of Production Economics, 138(2), 215241.

40. Emeç, Ş., \& Akkaya, G. Stochastic AHP and fuzzy VIKOR approach for warehouse location selection problem. Journal of Enterprise Information Management, 31(6), 950-962, 2018.

41. Akkaya, G., Turanoğlu, B., \& Öztaş, S. An integrated fuzzy AHP and fuzzy MOORA approach to the problem of industrial engineering sector choosing. Expert Systems with Applications, 42(24), 9565-9573, 2015.

42. Emeç, Ş.,\&Akkaya, G. Sağlık Sektöründe Zihinsel İş Yükü Değerlendirilmesi ve Bir Uygulama. Ergonomics, 1(3), 156-162, 2018. 